Special issue of the 3rd International Conference on Computational and Experimental Science and Engineering (ICCESEN 2016)

\title{
Comparison of Mechanical Properties of Unidirectional and Woven Carbon, Glass and Aramid Fiber Reinforced Epoxy Composites
}

\author{
S. EKŞI* AND K. GENEL \\ Sakarya University, Mechanical Engineering Department, Sakarya, Turkey
}

\begin{abstract}
In this study, mechanical behavior of epoxy composite reinforced by unidirectional and woven fiber is investigated experimentally. In the preparation of composite samples woven shaped glass, aramid and carbon fibers and unidirectional shaped glass and carbon fibers were used. Tension, compression and shear tests were carried out to determine mechanical properties of composites. It is seen from the test results, that unidirectional carbon fiber shows better performance than the glass fiber. Mechanical properties of $0^{\circ}$-oriented unidirectional fiber are better than those of $90^{\circ}$-oriented unidirectional fiber. Mechanical properties of aramid-fiber-reinforced composite are higher than those of glass and carbon fiber, when the woven types of fibers are considered.
\end{abstract}

DOI: 10.12693/APhysPolA.132.879

PACS/topics: 81.05.-t, 81.05.Kf, 81.05.Ni, 81.05.U-, 81.70.-q

\section{Introduction}

Composites are becoming an essential part of today's materials because they offer such advantages as low weight, corrosion resistance, high fatigue strength, faster assembly, etc. Composites are used as materials for various applications, ranging from making aircraft structures to golf clubs, electronic packaging to medical equipment and from space vehicles to home building [1].

Design goals of fiber-reinforced composites often include high strength and/or stiffness at a given weight. These characteristics are expressed in terms of specific strength and specific modulus parameters, which correspond, respectively, to the ratios of tensile strength to specific weight and modulus of elasticity to specific weight. Fiber-reinforced composites with exceptionally high specific strengths and moduli have been already produced, that use low-density fiber and matrix materials [2].

Many researchers have done studies on fiber reinforced epoxy composites. Generally glass, carbon and aramid are used as fiber material. Mechanical properties of fiber reinforced composites in these studies are investigated experimentally, numerically and analytically [3-18]. There are also some studies on basalt fiber and hydrojel composites [19, 20]

Frangopol et al. investigated the reliability of a composite laminate plate by using Tsai-Wu failure criterion. Fiber orientation, layer thickness and number have a significant effect on the reliability of fiber reinforced composite plates [3]. Mortazavian et al. investigated the anisotropy effects on tensile properties of two short glass-fiber-reinforced thermoplastics experimentally and

*corresponding author; e-mail: eksi@sakarya.edu.tr analytically. Laminate analogy and modified Tsai-Hill criteria provided satisfactory predictions of elastic modulus and tensile strength [4]. Flexural properties of bidirectional hybrid epoxy composites reinforced with glass and carbon fiber were investigated experimentally and using finite element analyses by Dong et al. [6].

Failure analysis of composite laminates subjected to tension, shear and compression were investigated by numerical analyses and experimentally $[7,8]$. High strain rate out-of-plane properties of aramid fabric reinforced polyamide composite are investigated experimentally. Influence of strain rate on the tensile and compression properties of glass, carbon and aramid reinforced epoxy/polyamide composites are studied experimentally and theoretically in $[9,10]$.

Wicaksono et al. investigated the material properties of woven carbon fiber-reinforced plastic material subjected to static and fatigue loading. They found good correlations between predicted and experimental results [13]. In our previous study we investigated experimentally the bending behavior of hybrid composites reinforced by woven fiber. Load carrying capacity of hybrid tubes increased 7 times and energy absorbing capacity 9.6 times, respectively [14]. Ozsoy et al. investigated the tensile, bending, impact and hardness properties of chopped carbon fiber reinforced epoxy composites with varied weight fractions. They have shown that tensile, bending and impact performances have increased up to $8 \%$ of carbon fiber in the composite and then started to decrease [16].

In this study, we investigated the mechanical properties of unidirectional (glass and carbon) and woven (glass, aramid and carbon) fiber reinforced epoxy composites. Tensile, shear and compression behavior of composites were investigated.

\section{Experimental studies}

In this study, mechanical behavior of woven and unidirectional fiber reinforced epoxy composites was investi- 
gated in a systematic experimental procedure. The fiber components utilized in specimen preparation are twill-structured glass fiber $\left(280 \mathrm{~g} / \mathrm{m}^{2}\right)$, twill-structured aramid fiber $\left(170 \mathrm{~g} / \mathrm{m}^{2}\right)$, plain-structured carbon fiber $\left(200 \mathrm{~g} / \mathrm{m}^{2}\right), 300 \mathrm{~g} / \mathrm{m}^{2}$ unidirectional glass and $350 \mathrm{~g} / \mathrm{m}^{2}$ unidirectional carbon fiber. Each test was repeated on three specimens and the average values were considered. Images of fiber material are given in Fig. 1.

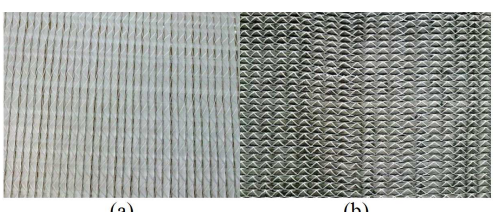

(a) (b)

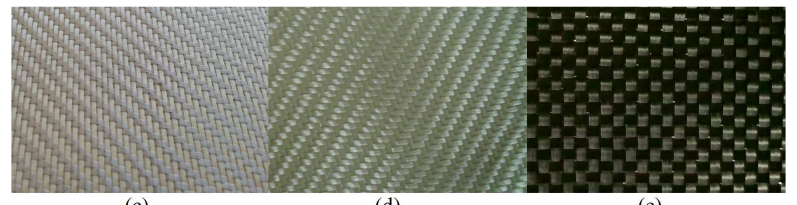

(c) (d)

(MGS L285) was mixed with hardener (HGS L285) in volume ratio of $100 / 50$, as is recommended by the supplier. Tension, compression and shear test specimens were cut according to the ASTM D3039 [21], ASTM D3410 [22] and ASTM D3518 [23]. Steel plates were glued to edges of some specimens to prevent failure. Load measurements were performed with Instron machine (Fig. 2). Video extensometer was used in the tests. Tension and shear tests were carried out at $2 \mathrm{~mm} / \mathrm{min}$ and compression tests at $1.5 \mathrm{~mm} / \mathrm{min}$.

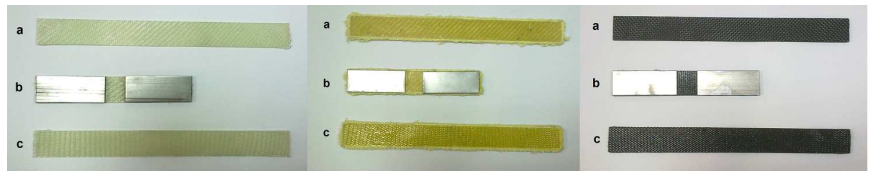

Fig. 3. Tension, compression and shear test specimens of woven glass, aramid and carbon fiber reinforced epoxy composites, (a) tension test specimen, (b) compression test specimen, (c) shear test specimen.
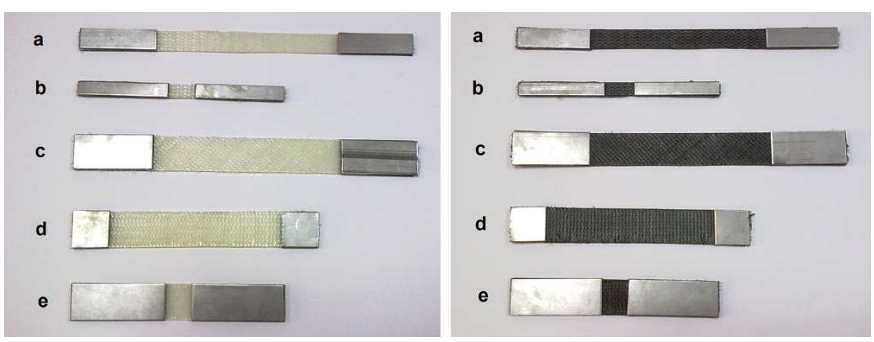

Fig. 4. Tension, compression and shear test specimens of unidirectional glass and carbon fiber (a) $0^{\circ}$ orientation tension test specimen, (b) $0^{\circ}$-orientation compression test specimen, (c) $0^{\circ}$-orientation shear test specimen, (d) $90^{\circ}$-orientation tension test specimen, (e) $90^{\circ}$-orientation compression test specimen.

Tensile, compressive and shear tests samples are given in Figs. 3 and 4.

\section{Experimental results}

Mechanical test results of unidirectional and woven fiber reinforced epoxy composites and tensile strength ratio of unidirectional fiber reinforced epoxy composites are given in Tables I and II. Mechanical properties of fiber reinforced composites obtained from tests are given in Table I. Tensile strength ratios of unidirectional fiber reinforced epoxy composites are given in Table II.

Results from obtained tests are in accordance with literature. However, there are some little difference in values compared to literature, due to fact that composites were manufactured by manual lay-up process. Optimum results of woven fiber reinforced epoxy composite were obtained in aramid reinforced epoxy composite. Carbon fiber reinforced epoxy composite have better results than glass reinforced epoxy composite, among the unidirectional fiber reinforced epoxy composites. 
TABLE I

Mechanical properties of fiber reinforced composites obtained from tension, compression and shear tests.

\begin{tabular}{c|c|c|c|c|c|c|c|c|c|c}
\hline \hline $\begin{array}{c}\text { Reinforcement } \\
\text { type }\end{array}$ & $\begin{array}{c}\text { Volume } \\
\text { of fiber } \\
V_{\mathrm{f}}\end{array}$ & $\begin{array}{c}\text { Density } \\
{\left[\mathrm{g} / \mathrm{cm}^{3}\right]}\end{array}$ & $\begin{array}{c}\text { Elasticity } \\
\text { module } \\
{[\mathrm{MPa}]}\end{array}$ & $\begin{array}{c}\text { Shear } \\
\text { module } \\
{[\mathrm{MPa}]}\end{array}$ & $\begin{array}{c}\text { Poison } \\
\text { ratio } \\
{[-]}\end{array}$ & $\begin{array}{c}\text { Tensile } \\
\text { strength } \\
{[\mathrm{MPa}]}\end{array}$ & $\begin{array}{c}\text { Tensile } \\
\text { strength/ } / \\
\text { density }\end{array}$ & $\begin{array}{c}\text { Shear } \\
\text { strength } \\
{[\mathrm{MPa}]}\end{array}$ & $\begin{array}{c}\text { Compression } \\
\text { strength } \\
{[\mathrm{MPa}]}\end{array}$ & $\begin{array}{c}\text { Elongation } \\
\text { at break }\end{array}$ \\
\hline Woven glass & 30 & 1.55 & 14352 & 4728 & 0.24 & 220 & 141.9 & 119 & 96 & 0.016 \\
Woven aramid & 30 & 1.2 & 19087 & 2585 & 0.38 & 357 & 297.5 & 53 & 64 & 0.019 \\
Woven carbon & 30 & 1.31 & 42000 & 12350 & 0.32 & 340 & 259.5 & 180 & 118 & 0.009 \\
Unidir. glass $\left(0^{\circ}\right)$ & 30 & 1.55 & 18300 & 3895 & 0.25 & 432 & 278.7 & 30 & 71 & 0.028 \\
Unidir. glass $\left(90^{\circ}\right)$ & 30 & 1.55 & 7940 & 3895 & 0.17 & 52 & 33.5 & 30 & 16 & 0.0096 \\
Unidir. carbon $\left(0^{\circ}\right)$ & 30 & 1.31 & 78715 & 2195 & 0.4 & 826 & 630.5 & 20 & 118 & 0.0100 \\
Unidir. carbon $\left(90^{\circ}\right)$ & 30 & 1.31 & 4930 & 2195 & 0.25 & 37 & 28.2 & 20 & 27 & 0.0130 \\
\end{tabular}

TABLE II

Tensile strength ratio of unidirectional fiber reinforced epoxy.

\begin{tabular}{c|c}
\hline \hline $\begin{array}{c}\text { Unidirectional fiber } \\
\text { reinforced epoxy }\end{array}$ & $\begin{array}{c}\text { Tensile strength } \\
\text { ratio }\end{array}$ \\
\hline $0^{\circ}$ glass $/ 90^{\circ}$ glass & 8.3 \\
$0^{\circ}$ carbon $/ 90^{\circ}$ carbon & 22.3 \\
$0^{\circ}$ carbon $/ 0^{\circ}$ glass & 1.91 \\
$90^{\circ}$ carbon $/ 90^{\circ}$ glass & 0.71
\end{tabular}

Maximum improvement is obtained in $0^{\circ}$-orientation fiber in unidirectional fiber reinforced epoxy composites compared to the $90^{\circ}$ orientation. Improvement ratio of tensile strength in $0^{\circ}$ glass epoxy composites is 8.3 with respect to $90^{\circ}$-orientation glass fiber reinforced epoxy. Improvement ratio of tensile strength in $0^{\circ}$-orientation carbon fiber epoxy composites is 22.3 with respect to $90^{\circ}$-orientation carbon fiber reinforced epoxy (Table II).

The best result of tensile strength/density ratio is found in unidirectional $0^{\circ}$-orientation carbon fiber reinforced epoxy with value of 630.5. It is followed by the woven aramid fiber reinforced epoxy with ratio value of 297.5. Elasticity module of $0^{\circ}$-orientation glass fiber reinforced epoxy is 2.3 times higher than that of $90^{\circ}$-orientation glass fiber reinforced epoxy due to elasticity module of $0^{\circ}$-orientation carbon fiber reinforced epoxy, which is 15.9 times higher than that of $90^{\circ}$-orientation carbon fiber reinforced epoxy. Tensile strength of $0^{\circ}$-orientation carbon fiber reinforced epoxy is approximately 2 times higher than that of glassreinforced, however the ratio of elasticity modules of $0^{\circ}$-orientation carbon fiber to that of $0^{\circ}$-orientation glass fiber is 4.3 .

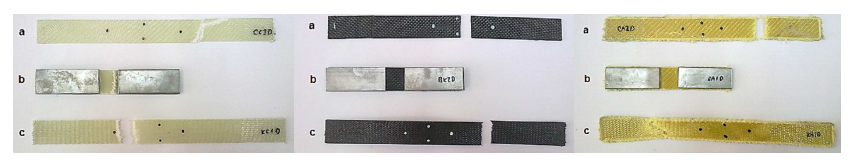

Fig. 5. Woven glass, carbon and aramid reinforced composite after tests, (a) tensile test, (b) compression test, (c) shear test.
The image of the fiber reinforced epoxy composites after tests is given in Figs. 5 and 6.

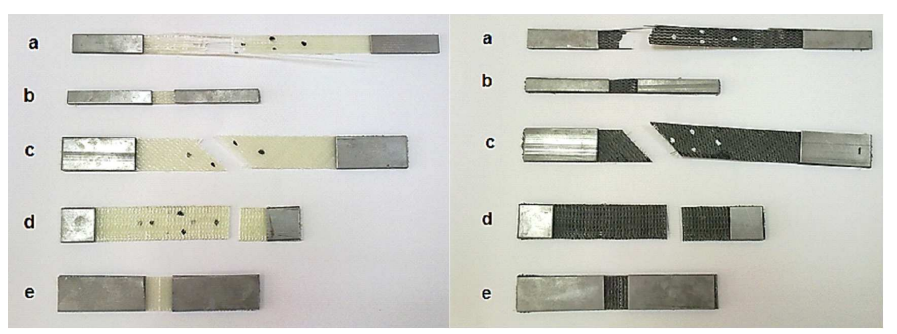

Fig. 6. Unidirectional glass and carbon reinforced composite after tests, (a) tensile test at $0^{\circ}$ orientation, (b) compression test at $0^{\circ}$ orientation, (c) unidirectional shear test, (d) tensile test at $90^{\circ}$ orientation, (e) compression test at $90^{\circ}$ orientation.

\section{Conclusions}

In this study, mechanical properties of woven and unidirectional fiber reinforced epoxy composites were investigated. The results obtained from the experiments show that elasticity module, shear and compression strengths of composites with unidirectional carbon fiber reinforced epoxy composite have the best performance, compared to the glass fiber reinforced epoxy composite. Mechanical properties of $0^{\circ}$-orientation carbon fiber reinforced composite is higher than those of $90^{\circ}$-orientation carbon fiber reinforced composite. Tensile strength at $0^{\circ}$ orientation of unidirectional glass fiber is 8.3 times higher than that of $90^{\circ}$-orientation. This value in carbon fiber reinforced epoxy composite is 22.3. Mechanical properties of aramid fiber reinforced epoxy composite are stronger than those of glass and carbon fiber reinforced epoxy composite among the woven types of fibers. Tension strength of woven aramid reinforced epoxy composite is 1.5 times higher than that of woven glass reinforced epoxy composite due to elasticity module of woven carbon reinforced epoxy composite, which is higher than in the others. 


\section{References}

[1] A.K. Kaw, Mechanics of composite materials, 2nd ed. Taylor \& Francis Group, LLC 2006.

[2] W.D. Callister Jr, D.G. Rethwisch, Introduction in: Materials science and engineering, 8th ed., John Willey \& Sons, 2007.

[3] D.M. Frangopol, S. Recek, Probabilist. Eng. Mech. 18, 119 (2003)

[4] S. Mortazavian, A. Fatemi, Compos.: Part B 72, 116 (2015).

[5] W. Sun, A.P. Vassilopoulos, T. Keller, Compos. Struct. 130, 9 (2015).

[6] C. Dong, I.J. Davies, Compos.: Part B 72, 65 (2015).

[7] H. Hu, W. Lin, F. Tu, Compos.: Part B 83, 153 (2015).

[8] J.L.Y. Tan, V.S. Deshpande, N.A. Fleck, Compos.: Part A 77, 56 (2015).

[9] K. Naresh, K. Shankar, B.S. Rao, R. Velmurugan, Compos.: Part B 100, 125 (2016).

[10] X. Qian, H. Wang, D. Zhang, G. Wen, Polym. Test. 53, 314 (2016).

[11] C. Dong, Compos.: Part B 98, 176 (2016).

[12] X. Gao, J.W. Gillespie Jr, R.E. Jensen, W. Li, B.Z. (Gama) Haque, S.H. McKnight, Compos.: Part A 74, 10 (2015).

[13] S. Wicaksono, G.B. Chai, Compos. Struct. 119, 185 (2015).
[14] S. Ekşi, K. Genel, Acta Phys. Pol. A 128, B-59 (2015).

[15] N. Ozsoy, M. Ozsoy, A. Mimaroglu, Acta Phys. Pol. A 128, B-55 (2015).

[16] N. Ozsoy, M. Ozsoy, A. Mimaroglu, Acta Phys. Pol. A 130, 297 (2016).

[17] I.K. Yilmazcoban, S. Doner, Acta Phys. Pol. A 130, 342 (2016).

[18] N. Çiçek Bezir, A. Evcin, R. Kayali, M. Kaşikçi Özen, K. Esen, B. Cambaz, Acta Phys. Pol. A 130, 300 (2016).

[19] C.P. Ndepete, S. Sert, Acta Phys. Pol. A 130, 355 (2016).

[20] F. Akti, F. Boran, Acta Phys. Pol. A 130, 147 (2016).

[21] ASTM D3039/D3039M-14 Standard Test Method for Tensile Properties of Polymer Matrix Composite Materials.

[22] ASTM D3410/D3410M-16 Standard Test Method for Compressive Properties of Polymer Matrix Composite Materials with Unsupported Gage Section by Shear Loading.

[23] ASTM D3518/D3518M-13 Standard Test Method for In-Plane Shear Response of Polymer Matrix Composite Materials by Tensile Test of a $\pm 45^{\circ}$ Laminate. 